\title{
An immunohistochemical study of Flexibacter psychrophilus infection in experimentally and naturally infected rainbow trout (Oncorhynchus mykiss) fry
}

\author{
Øystein Evensen ${ }^{1, *}$, Ellen Lorenzen ${ }^{2}$ \\ ${ }^{1}$ Central Veterinary Laboratory, Department of Pathology, PO Box 8156 Dep., N-0033 Oslo, Norway \\ ${ }^{2}$ Danish Veterinary Laboratory, Hangøvej 2, DK-8200 Århus N, Denmark
}

\begin{abstract}
An immunohistochemical method is described for the detection of Flexibacter psychrophilus in formalin-fixed, paraffin-wax-embedded fry of rainbow trout. Rabbit antiserum as well as rainbow trout hyperimmune serum were used in the study. The distribution and tissue localization of the bacterium was compared in naturally and experimentally (intraperitoneal injections) infected fry by use of immunohistochemistry. This study showed that $F$. psychrophilus could be detected in paraffinwax-embedded tissue of rainbow trout fry by immunohistochemistry. The principal immunohistochemical findings in naturally and experimentally infected fry showed that there was a localization of bacteria in the monocyte-macrophage system, in skin lesions, and in the retina and the choroid giand of the eye. The dermal changes included superficial or deep ulcers extending to the subcutaneous tissue or the musculature accompanied by inflammatory cell infiltrates in which polymorphonuclear inflammatory cells were shown to contain the bacterium in the cytoplasm by immunostaining. The eye changes were likewise a common finding in chronic cases with severe inflammatory changes in the retina and with numerous bacteria in inflammatory (mainly polymorphonuclear) cells. F. psychrophilus infection in rainbow trout fry involves the monocyte-macrophage system extensively, and the concurrent localization of bacteria in the skin ulcers and retinal inflammation points to the probable involvement of the bacterium in the development of the lesions which are typically found during the chronic stage of the disease.
\end{abstract}

KEY WORDS: Immunohistochemistry - Flexibacter psychrophilus - Rainbow trout · Fry

\section{INTRODUCTION}

During the last $10 \mathrm{yr}$, rainbow trout fry syndrome (RTFS) has caused high mortalities among rainbow trout Oncorhynchus mykiss fry in most European hatcheries (Bernardet et al. 1988, Lehmann et al. 1988, Lorenzen et al. 1991, Santos et al. 1992, Sarti et al. 1992, Toranzo \& Barja 1993). Typical gross changes in diseased fry include anaemia (with pallor of the gills, liver, and kidney), splenomegaly, a white and fragile intestine, and a haemorrhagic, protruding anus (Baudin-Laurencin et al.

•E-mail: oystein.evensen@vetinst.no
1989, Lorenzen et al. 1991). Fingerlings and larger rainbow trout usually show less obvious signs, the most pronounced ones being blindness, moderate anaemia, visceral petechiae and ecchymoses, skin lesions in the region of the dorsal fin or on the flank, lordosis/scoliosis, and abnormal swimming behaviour (Dalsgaard \& Hørlyck 1990, Bruno 1992, Santos et al. 1992, E. Lorenzen, I. Dalsgarrd \& J. F. Bernadet unpubl.).

Since the 1940 s a disease known as peduncle disease (Davis 1946, cited by Bullock et al. 1971) or (bacterial) cold water disease [(B)CWD] (Wood \& Yasutake 1956, Borg 1960, Bullock et al. 1971, Holt et al. 1989) has caused major problems in the USA among hatchery-reared sac fry and fingerlings, particularly in coho 
salmon Oncorhynchus kisutch. Erosion of the skin of the yolk sac, and lesions on the head and the peduncle region or near the vent in fry and fingerlings, are typical findings in acute and sub-acute stages (Davis 1946 cited by Bullock et al. 1971, Borg 1960, Bullock et al. 1971, Wood 1974). In chronically infected fish typical signs are spiral swimming behaviour and vertebral deformities (Conrad \& DeCew 1967, Kent et al. 1989).

Flexibacter psychrophilus is involved in CWD as well as in RTFS (Baudin-Laurencin et al. 1989, Lorenzen et al. unpubl.). The pathological changes associated with CWD have been described in naturally infected fish, including coho salmon (Wood \& Yasutake 1956, Borg 1960, Kent et al. 1989), and in experimental infections (Otis 1984, referred to by Holt et al. 1993). Howevel, there are few studies of RTFS describing the histopathological changes in naturally or experimentally infected fish in Europe (Chua 1991, Bruno 1992) and of the relation of the changes to the presence of bacteria in different cell/tissue compartments. This is largely due to the fact that in situ visualization of $F$. psychrophilus can hardly be achieved using haematoxylin and eosin staining ( $\mathrm{H}$ \& E) (Bruno 1992) or using Gram-staining (authors' unpublished results). Giemsa and Warthin-Starry have been used for staining the bacteria (Wood \& Yasutake 1956, Kent et al. 1989, Lorenzen et al. 1991), but none of these methods is specific, and bacteria might be confused with tissue components, especially pigment granules.

The objectives of the present study were to develop an immunohistochemical technique for in situ identification of Flexibacter psychrophilus in paraffin-waxembedded tissues of rainbow trout fry, and to use the technique to study the tissue distribution and tissue/ cell localization of the bacterium in naturally and experimentally infected fry.

\section{MATERIALS AND METHODS}

Fish from natural outbreaks. Fry were sampled from clinical outbreaks of RTFS at 5 different Danish rainbow trout hatcheries during the summer of 1993. At farms I to III, there was a clinical outbreak of RTFS and the fry showed gross changes typical of the disease. At farms IV and $V$, the infection was in a chronic stage and the fry were in the phase of recovery from the disease with characteristic skin lesions around the dorsal fin and clinical signs of blindness. The diagnosis was verified by clinical examination of diseased fry and by isolation of Flexibacter psychrophilus as described below or after identification of the bacterium in spleen smears by use of an immunofluorescence technique (Lorenzen \& Karas 1992)
Fish for experimental infection. A batch of approximately 300 rainbow trout fry Oncorhynchus mykiss from a Danish hatchery without any previous history of RTFS was brought to the Danish Veterinary Laboratory, Århus, Denmark, 4 wk before infection for acclimation to the aquarium facilities. Before and during the experimental period, the fry were kept at $14^{\circ} \mathrm{C}$ in non-chlorinated flow-through tap water and fed commercial trout feed (Ecostart 17, produced by Dansk Ørredfoder A/S).

Experimental infection. At a mean weight of $0.85 \mathrm{~g}$. 100 fry (in 2 parallel tanks containing 50 fish each) were infected under anaesthesia $10.1 \%$ alcoholic solution of benzocaine) by intraperitoneal injection of $2 \times$ $10^{7} \mathrm{CFU}$ of a low-passage broth culture of Flexibacter psychrophilus (strain No.729-2, serotype Th, isolated from a Danish hatchery). The bacterium had been grown for $2 \mathrm{~d}$ in modified Cytophaga broth, AOBE (Lorenzen 1993), on an orbital shaker (80 to $90 \mathrm{rpm}$ ) at $15^{\circ} \mathrm{C}$. Fifty control fry were injected with a corresponding volume $(50 \mu \mathrm{l})$ of AOBE. For histological and bacteriological examinations, 3 fry from each tank were sampled sequentially beginning $6 \mathrm{~h}$ after infection and thereafter approximately every $24 \mathrm{~h}$ during the following $18 \mathrm{~d}$. When available, moribund fry were sampled. Control fry ( 6 fish) were sampled at $6 \mathrm{~h}$ after injection.

Bacteriological isolation/identification. Spleens from experimentally or naturally infected fry were spread on modified Cytophaga agar (AOAE) and blood agar in parallel, and incubated for $14 \mathrm{~d}$ at $15^{\circ} \mathrm{C}$ and $7 \mathrm{~d}$ at $20^{\circ} \mathrm{C}$, respectively. Identification of yellow-pigmented bacteria on AOAE was based on morphology of colonies, morphology and motility of the bacteria in wet mount preparations, reactivity with the APIZYMgallery (La Balme-les-Grottes, Montalieu-Vercieu, France), $10 \% \mathrm{KOH}, 30 \% \mathrm{H}_{2} \mathrm{O}_{2}$ and $\mathrm{N}, \mathrm{N}$-dimethyl-1,4phenylene di-ammonium chloride; 1-naphthol [Oxidase Test (Roche), F. Hoffmann-La Roche \& Co. Ltd., Basle, Switzerland] according to Bernardet \& Grimont (1989) and Lorenzen et al. (unpubl.). In addition, the serological reactivity of the bacteria was tested with polyclonal antisera raised against the 3 Danish serotypes of Flexibacter psychrophilus by slide agglutination. The antisera included anti-Th, which is described below, anti-Fd, which was raised against the Danish strain 900530-4/2, and anti- $F \mathrm{p}^{\mathrm{T}}$, which was raised against the American type strain, F psychrophilus NCIMB $1947^{\mathrm{T}}$

Virus isolation. Homogenized tissue from kidney, spleen, and brain from 8 rainbow trout fry from a clinical outbreak of infectious pancreatic necrosis (IPN) (RTFS) was inoculated onto BF-2 cell cultures and virus identification was performed by simultaneous neutralization as described (Vestergaard Jørgensen 
1974). IPN virus serotype Sp was isolated from the cell cultures and the average virus titer in the fry was $7.9 \times$ $10^{7} \mathrm{TCID}_{50} \mathrm{ml}^{-1}$

Fixation of organ specimens. Fry were killed by incision of the spinal cord and the whole fish was immediately submerged in $10 \%$ phosphate buffered formalin ( $\mathrm{pH} 7.2$ to 7.4 ), for at least $24 \mathrm{~h}$ at $4^{\circ} \mathrm{C}$. Fry were then embedded in paraffin wax according to standard procedures. Sections were cut at 5 to $6 \mu \mathrm{m}$ and placed on either gelatin-coated slides for immunohistochemical staining, or on non-coated slides for $\mathrm{H} \& \mathrm{E}$ staining in preparation for morphological evaluation.

Antisera. The rabbit antiserum (anti-Th) was raised against a Danish strain of Flexibacter psychrophilus (911209-1). The rainbow trout hyperimmune serum IV -27 was collected from a naturally immunized breeding fish with an enzyme-linked immunoassay (ELISA)titer against $F$. psychrophilus strain no. 911209-1 of 1:40000. The serum NL-20 was collected from a rainbow trout not previously exposed to F. psychrophilus, and its ELISA-titer was less than 1:40.

Monoclonal antibodies (MAbs). MAb, 4C10, against rainbow trout IgM heavy chain, was kindly provided by $\operatorname{Dr} A$. Thuvander (Thuvander et al. 1990).

Immunohistochemistry. The immunohistochemical staining was performed as described previously (Rimstad \& Evensen 1993, Evensen et al. 1994) with a few modifications. After deparaffinization, endogenous peroxidase activity was blocked when necessary by incubating for $40 \mathrm{~min}$ at $37^{\circ} \mathrm{C}$ with $0.05 \%$ phenyl hydrazine (Sigma) in Tris-buffered saline (TBS). Nonspecific binding sites were blocked by incubation with $5 \%$ bovine serum albumin ( $w / v, B S A$, Sigma) in TBS for $20 \mathrm{~min}$. The subsequent incubation steps were as described below. The rabbit antiserum, antiTh, (which showed similar reactivity in fry experimentally infected with each of the 3 serotypes, Th, Fd or $\mathrm{Fp}^{\mathrm{T}}$ of Flexibacter psychrophilus was diluted $1: 2000$ or $1: 10000$ and incubated for $30 \mathrm{~min}$. The trout hyperimmune serum was diluted 1:10000 and incubated overnight at $4^{\circ} \mathrm{C}$. The subsequent step was a 30 min incubation with biotin-conjugated goat antirabbit IgG $(\mathrm{H}+\mathrm{L})$ (Vector) diluted 1:300 when rabbit antiserum was used. For trout hyperimmune serum, the subsequent step was a $1 \mathrm{~h}$ incubation with MAb 4 C10 (supernatant of anti-trout IgM) diluted 1:50. The sections were then rinsed and washed before incubation for $30 \mathrm{~min}$ with either biotin-conjugated rabbit anti-mouse IgG (Dako) diluted 1:300 or with horse radish-peroxidase conjugated sheep anti-mouse IgG (Amersham) diluted 1:50. The last incubation steps were with either Streptavidin-alkaline phosphatase (Boehringer Mannheim) diluted 1:1000 (30 min) or with avidin-biotin-peroxidase (ABC-PO,
Vector) diluted according to the manufacturer's instructions (45 min). After washing, the specimens were incubated with Fast Red $\left(1 \mathrm{~g} \mathrm{l}^{-1}\right)$ in $0.1 \mathrm{M}$ Tris$\mathrm{HCl}$ buffer, pH 8.2, containing naphthol AS-MX phosphate $\left(0.2 \mathrm{~g} \mathrm{l}^{-1}\right.$, Sigma), and N,N-dimethylformamide (20 $\mathrm{ml} \mathrm{l}^{-1}$, Sigma) and $1 \mathrm{mM}$ levamisole (Sigma) as inhibitor of alkaline phosphatase. Incubation was for $20 \mathrm{~min}$ at room temperature. For peroxidase enzyme complexes, AEC (3-amino-9-ethylcarbazole, $0.27 \mathrm{~g} \mathrm{l}^{-1}$, Sigma) was dissolved in N,Ndimethylformamide $\left(67 \mathrm{ml} \mathrm{l}^{-1}\right)$ in $0.1 \mathrm{M}$ acetate buffer, $\mathrm{pH} 5.2$, containing $0.03 \% \mathrm{H}_{2} \mathrm{O}_{2}$, and the sections were incubated for $15 \mathrm{~min}$. Sections were then washed in running tap water for $10 \mathrm{~min}$, counterstained with Mayer's haematoxylin for $2 \mathrm{~min}$, and coverslipped with an aqueous medium (Aquamount, BDH-Laboratory Supplies).

Immunohistochemical periormance controls. Rainbow trout fry with clinical signs of RTFS were incubated with pre-immune rabbit antiserum or trout serum NL-20 at the same dilutions as used for the rabbit antiserum and trout hyperimmune serum, respectively. Fry from a batch without any previous history of RTFS were incubated with rabbit antiserum or with trout hyperimmune serum as well. Endpoint dilution of the rabbit antiserum anti-Th and the trout hyperimmune serum IV-27 was determined by titrating the sera, using dilutions of $1: 2000,1: 10000,1: 25000$, $1: 50000,1: 100000,1: 200000,1: 500000$ and $1: 1000000$ and overnight incubation at $4^{\circ} \mathrm{C}$.

To test the specificity of the method, absorption was performed by incubating the immune sera overnight on a mill at $4^{\circ} \mathrm{C}$ with approximately $1 \times 10^{9} \mathrm{cells}^{-1}$ of Flexibacter psychrophilus (no. 911209-1, 900530-4/2 and $\mathrm{NCMB} 1947^{\mathrm{T}}$, i.e. strains representative for each of the 3 Danish serogroups). The sera were diluted 1:500 in PBS containing $15 \mathrm{mM}$ sodium azide. Following incubation, the immune sera were centrifuged at $4900 \mathrm{rpm}(3080 \times \mathrm{g}$. Sigma $4 \mathrm{~K} 10$, Struers) for $1 \mathrm{~h}$ and the supernatant was recovered and filtered through a $0.45 \mu \mathrm{m}$ filter. Sections of RTFS-positive fry were then incubated in parallel overnight at $4^{\circ} \mathrm{C}$ with absorbed and non-absorbed antisera diluted 1:10000, 1:25000, 1:50000 and 1:100000 (final dilution)

For evaluation of antibody specificity, tissue specimens of different organs from fish infected with heterologous bacteria (Aeromonas salmonicida, Yersinia ruckeri and Renibacterium salmoninarum) were incubated overnight with the immune sera anti-Th and IV27 diluted 1:10000. The following polyclonal antisera served as positive controls: Antisera against $Y$. ruckeri and A. salmonicida were diluted 1:10000, and a protein A-purified fraction of antiserum against $R$. salmoninarum, kindly provided by Dr S. Gudmundsdottir, Keldur, Iceland, was diluted 1:300. 


\section{RESULTS}

\section{Bacterial isolation}

Flexibacter psychrophilus was isolated from all batches of naturally infected fry tested and no other pathogenic bacteria were detected. The isolated strains were agglutinated by one or more of the antisera (anti-Th, anti-FD or anti-Fp ${ }^{T}$ ). Bacteria were reisolated from the experimentally infected fry from 6 to $94 \mathrm{~h}$ after injection. Apart from fry sampled $6 \mathrm{~h}$ post injection, gross pathological changes and clinical signs

Table 1. Oncorhynchus mykiss. Principal findings by immunohistochemistry $(1 \mathrm{H})$ for fry collected from natural and experimental infections with Flexibacter psychrophilus

\begin{tabular}{|c|c|c|}
\hline Cell/tissue localization & $\begin{array}{l}\text { Natural } \\
\text { fection IH }\end{array}$ & $\begin{array}{l}\text { Experimental } \\
\text { infection } \mathrm{IH}^{\mathrm{a}}\end{array}$ \\
\hline \multicolumn{3}{|l|}{ Phagocytes } \\
\hline Circulating phagocytes & + &,$+ 6 h \rightarrow 18 d$ \\
\hline Endothelial cell adherent (kidney) & + &,$+ 6 \mathrm{~h} \rightarrow 18 \mathrm{~d}$ \\
\hline Melanomacrophages (kidney) & + &,$+ 12 \mathrm{~d} \rightarrow 18 \mathrm{~d}$ \\
\hline Splenic macrophages (pulp) & - &,$+ 6 h \rightarrow 18 d$ \\
\hline Splenic melanomacrophages & + & $+.27 \mathrm{~h} \rightarrow 18 \mathrm{~d}$ \\
\hline \multicolumn{3}{|l|}{ Skin } \\
\hline Epidermis/dermis & + & - \\
\hline Subcutaneous tissue & + & $+.27 \mathrm{~h} \rightarrow 12 \mathrm{~d}$ \\
\hline Mouth region & + & - \\
\hline \multicolumn{3}{|l|}{ Eye } \\
\hline Choroid gland & + & $+.27 \mathrm{~h} \rightarrow 12 \mathrm{~d}$ \\
\hline Retina (heavily inflamed) & + &,$- 27 \mathrm{~h} \rightarrow 12 \mathrm{~d}$ \\
\hline \multicolumn{3}{|l|}{ Abdominal cavity } \\
\hline Peritoneal phagocytic cells & - &,$+ 6 \mathrm{~h} \rightarrow 18 \mathrm{~d}$ \\
\hline Free bacteria in peritoneal cavity & - &,$+ 6 \mathrm{~h} \rightarrow 5 \mathrm{~d}$ \\
\hline \multicolumn{3}{|l|}{ Endothelial cells } \\
\hline Liver & - &,$+ 27 \mathrm{~h} \rightarrow 12 \mathrm{~d}$ \\
\hline Kidney & + &,$+ 6 \mathrm{~h} \rightarrow 18 \mathrm{~d}$ \\
\hline
\end{tabular}

of RTFS occurred in all other samplings and the changes and signs coincided with the detection of bacteria by cultivation.

\section{Immunohistochemical findings: natural vs experimental infection}

Flexibacter psychrophilus was identified in formalinfixed and paraffin-wax-embedded specimens in naturally and experimentally infected fry. The in situ localization of the bacterium in different cells and tissue compartments was generally similar for the 2 groups of fish but there were some major differences. The findings are summarized in Table 1, which also indicates the time-course in the spread of bacteria after intraperitoneal injection. The most typical results obtained by immunostaining were a positive identification of $F$. psychrophilus in different phagocyte populations, in various skin lesions, and in the retina and the choroid gland of the eye. The presence of the bacterium was regularly accompanied by inflammatory changes in naturally infected fry, but this did not occur to the same extent in experimentally infected fish.

Experimentally infected fry showed signs of infection $1 \mathrm{~d}$ after injection, characterized by lethargy, poor appetite, dark coloration of the skin, exophthalmia, and a tendency to 'hang' at the water surface. The clinical signs peaked at 36 to $48 \mathrm{~h}$, while at $94 \mathrm{~h}$ post injection and onwards, the survivors showed few discernible clinical or gross pathological changes.

By immunohistochemistry, bacteria/bacterial products were widely distributed in the peritoneal cavity after experimental infection (Fig. 1a), and were also taken up by intraperitoneal phagocytic cells (Fig. 1b) where they were detectable until the end of the experiment (Fig. 1b, Table 1). Bacteria and bacterial products were also distributed

Figs. 1 to 6. Oncorhynchus mykiss infected with Flexibacter psychrophilus. For all figures except Fig. 2, the immunohistochemical staining was performed using a trout hyperimmune serum (IV-27) and a Streptavidin-alkaline phosphatase technique with Fast Red as the chromogen. For Fig. 2, a Streptavidin-peroxidase complex was used with AEC as the chromogen. All sections were counterstained with Mayer's haematoxylin. Fig. 1. (a) Peritoneum, 6 h post injection. Numerous bacteria are found free in the peritoneal cavity. (b) At $96 \mathrm{~h}$ post injection, bacteria have been phagocytized by intraperitoneal phagocytic cells which display a strong cytoplasmic reaction (arrow). $\times 655$ (for both). Fig. 2. Head kidney, natural infection. An endothelial cell-adherent macrophage shows a strong cytoplasmic reaction (arrow). Interstitial phagocytic cells and melanomacrophages also display a strong cytoplasmic staining (open arrow). Note the distinct staining of the endothelial cells lining the sinusoids. $\times 415$. Fig. 3. Head kidney, natural infection. Incubation with a preimmune serum (IV20) gives no staining. $\times 415$. Fig. 4. Skin, natural infection. Single bacteria are identified in the epidermis (arrow). The adjacent area contains numerous bacteria and shows necrosis. Note cytoplasmic staining of infiltrating inflammatory cell, possibly a macrophage (open arrow). $\times 655$. Fig. 5 . Eye, retina, natural infection. Detail from basal layer of the retina (upper part) with numerous, distinctly visualized bacteria. Infiltrating macrophages are replete with bacteria/bacterial products (arrow). $\times 655$. Fig. 6 . Eye, choroid gland/retina, $56 \mathrm{~h}$ post injection. Strong staining apparently in endothelial cells lining the capillaries in the choroid gland $\times 415$ 


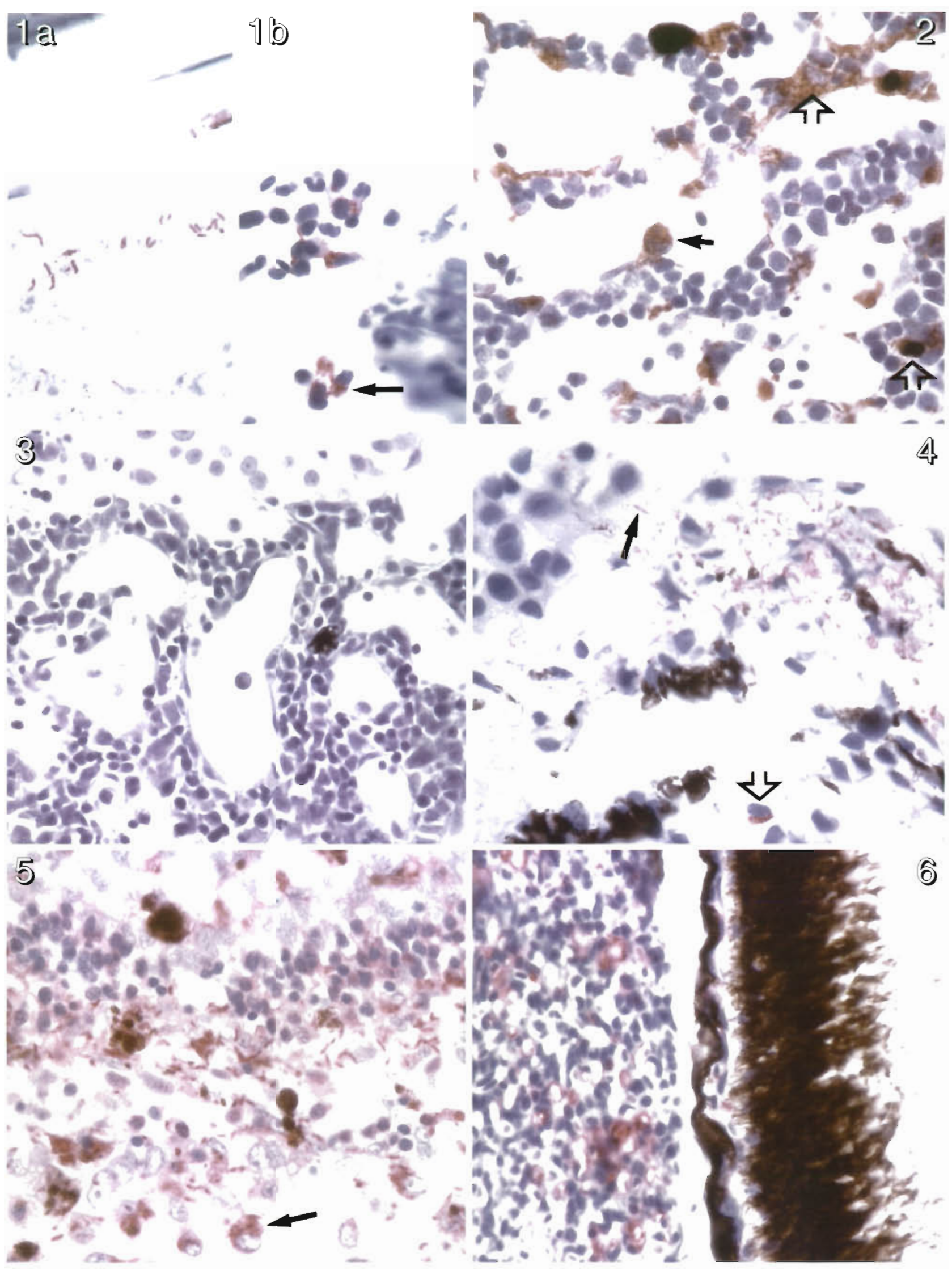


to the circulation and taken up by circulating monocytes and endothelial cell-adherent macrophages in the kidney (Table 1, Fig. 2). These findings occurred in both naturally and experimentally infected fry. The endothelial cell-adherent phagocytes in the kidney sinusoids were conspicuous by virtue of the intense cytoplasmic staining for the bacterium (Fig. 2), and the interstitial macrophages were frequently found to be replete with bacteria/bacterial products (Fig. 2). At a later stage (12 d) and until the end of the experiment, the bacteria were detected in interstitial melanomacrophages (Table 1), a localization of bacteria/bacterial products that was also typical of naturally infected fish. Focal necroses were also observed in the kidney interstitium accompanied by positive immunostaining (not shownj. The endotheilai celis of the kidney sinusolds, and to some extent the endothelial cells in liver sinusoids, were intensely positive by immunostaining and clearly outlined, especially cells around tubuli and in the sinusoids in the head kidney (Fig. 2). No staining of endothelial cells was observed in control fish or after substituting pre-immune serum for the immune serum (Fig. 3).

Splenic macrophages also showed a strong immunostaining for Flexibacter psychrophilus. However, this was not found in fish from natural outbreaks where the positive reaction was confined to melanomacrophages (Table 1)

Skin ulcers were not observed in the experimental group, but were consistently found in fish sampled from natural outbreaks. In such lesions Flexibacter psychrophilus was identified in the epidermis, the dermis, and in the cytoplasm of polymorphic inflammatory cells infiltrating the ulcerated skin (Fig. 4). These changes frequently extended down to the subcutaneous tissue. In natural outbreaks, a positive staining was typically also demonstrated in the loose connective tissue around the vertebrae, mainly associated with small veins (not shown).

Eye changes were a constant finding in chronically infected fish sampled from natural outbreaks. The basal parts of the retina were heavily infiltrated with inflammatory cells, mainly polymorphic granulocytes, the cytoplasm of which contained bacteria/bacterial products (Fig. 5). In contrast, in the experimental group, there was a positive immunostaining in endothelial cells of the choroid gland (Fig. 6), but this was not accompanied by morphological changes.

\section{Performance controls}

A comparison between the reactivity of rabbit antiserum anti-Th and trout hyperimmune serum IV-27 showed that the latter gave a more distinct reaction than the former with a clear visualization of single bacteria. Controls were negative for either or for both antigens. Pre-immune rabbit serum and non-immune trout serum NL-20 showed no reactivity when incubated with Flexibacter psychrophilus positive sections. Sections of fry without any previous history of RTFS showed no reaction with rabbit immune serum anti-Th or with trout serum IV-27. Endpoint dilution for anti-Th and IV-27 was $1: 500000$ and 1:200000, respectively. After absorption, the reactivity of anti-Th and IV-27 was negative at the lowest dilution used for the nonabsorbed antisera (1:10000, overnight incubation, $4^{\circ} \mathrm{C}$ ). When incubated on specimens from rainbow trout infected with Yersinia ruckeri or Renibacterium salmoninarum, IV-27 and anti-Th gave negative results. When incubated with specimens from Atlantic salmon infected with Aeromonas salmonicida, however, some reactivity was observed in the lumen of the intestine and in pancreas. This reactivity could be removed by absorption with $A$. salmonicida indicating a minor degree of cross-reactivity.

\section{DISCUSSION}

The present study showed that Flexibacter psychrophilus could be detected immunohistochemically in sections of paraffin-wax-embedded rainbow trout fry. Single bacteria were more distinctly visualized using a trout hyperimmune serum than a rabbit antiserum. The immunohistochemical findings with regard to the distribution of bacteria in different cells and tissue compartments in naturally and experimentally infected fry were comparable, but with some major exceptions, i.e. the skin changes in fish collected from natural outbreaks included infected ulcers with an accompanying infiltration of inflammatory cells, and the eye changes showed the presence of numerous bacteria in basal layers of the retina. These changes were not demonstrated in the course of the experimental infection.

Detection of Flexibacter psychrophilus in sections of paraffin-wax-embedded tissue specimens by use of standard laboratory staining methods has proved difficult (Wood \& Yasutake 1956, Kent et al. 1989, Meyers 1989. Chua 1991, Bruno 1992, authors' own observations), but bacteria can easily be demonstrated by immunofluorescence analysis of spleen imprints from diseased fish (Lorenzen \& Karas 1992). This method has been found to be rapid and satisfactory for diagnostic purposes, and also gives the opportunity to evaluate the morphology of the stained bacteria. For evaluating the distribution of the agent in different tissues, however, immunoenzyme methods applied to paraffin-embedded fry or tissue specimens show their 
superiority. In addition to being of value for diagnostic purposes, it is especially valuable for pathogenesis studies

The study also underlines the importance of adequate antibody specificity testing. Such evaluations have traditionally been done by running a homologous absorption test, i.e. by adding antigen in surplus to the antibody solution and thereby blocking all antibody binding sites, which should block the immunostaining (Petrusz 1983). The results obtained by this approach are greatly dependent on the purity of the antigen used, and the disappearance of staining following blocking does not necessarily validate the specificity, since contaminating antibodies can also be absorbed (Elias et al. 1989). Nevertheless, neither the trout hyperimmune serum nor the rabbit antiserum showed any reactivity with specimens positive for Yersinia ruckeri or Renibacterium salmoninarum antigens, and all reactivity in specimens positive for Flexibacter psychrophilus antigens disappeared following absorption with the homologous bacterial isolate (911209-1) and with heterologous isolates of $F$. psychrophilus (900530-4/2 and $\mathrm{Fp}^{\mathrm{T}}$ ). However, the antisera (anti-Th and IV-27) cross-reacted with Aeromonas salmonicida in situ, and heterologous absorption (with $A$. salmonicida) prevented this activity. The specificity was considered acceptable for the present purposes, but in cases of suspicion of furunculosis it would be crucial to use antiserum absorbed with $A$. salmonicida.

To our knowledge, there are no previous reports on the detection of Flexibacter psychrophilus in the eyes or the choroid gland. This might be caused by the fact that silver-stained bacteria contrast poorly with the pigment layer of the retina, and thus make differentiation difficult. By use of immunohistochemistry, and with Fast Red as a chromogen, the bacterium was readily visualized in the retina. The finding is of considerable interest, because of the observation that about 5 to $10 \%$ of fingerlings that recover from RTFS suffer from blindness. The inflammatory changes observed in the retinal layer could partly explain the clinical observations

In under-yearlings and fingerlings of rainbow trout, steelhead, and coho salmon that had recovered from BCWD, and exhibited spiral swimming behaviour and various spinal deformities, heavy inflammation and periosteal proliferation in the area of the junction of the anterior vertebrae with the cranium have been reported (Kent et al. 1989, Meyers 1989). In the present study, bacteria/bacterial products were demonstrated in the vicinity of the vertebrae. Even so, the connection between the in situ demonstration of bacteria/bacterial products and the spinal deformities is uncertain, and further studies should be pursued to define the relationship and mechanisms involved.
The mode of transmission as well as the port of entry of the bacterium are unknown. It has been proposed that infective myxobacteria (now cytophagas) invade the skin in the case of reduced resistance due to skin injuries (Roberts 1976). In the present study, bacteria were detected in skin lesions around the fins. Nevertheless, difficulties of infecting healthy fry by bath challenge (Holt 1987, authors' own observations), or by co-habitation (authors' own observation), mean that it is difficult to reproduce the disease in the labora:ory. Therefore, the route of infection of the bacterium still remains to be clarified.

The pathogenesis of the disease is also poorly understood. Experimental infections based on intraperitoneal injection shed little light on natural disease transmission, but some preliminary speculations on disease development may be appropriate. The bçcteria/bacterial products were rapidly taken up from the peritoneal cavity, agreeing with previous studies using particulate antigens (Ellis et al. 1976). Free bacteria and/or bacterial products reaching the vasculature were most likely taken up by phagocytes in the kidney sinusoids and in the spleen as shown in the experimental study ( 6 to $27 \mathrm{~h}$ post injection). The uptake of bacteria by intrasinusoidal kidney phagocytes was comparable to that seen in natural outbreaks, and late in the experimental period (Days 12 and 18), staining was demonstrated in melanomacrophage accumulations in the interstitial tissue of the kidney and spleen. The latter observations were also in agreement with the findings in naturally infected fry, especially in chronically infected fish, where bacteria/bacterial products were detected in melanomacrophages in the kidney and spleen. Earlier studies have demonstrated that injected particulate material (Salmonella bacteria) and soluble particles (carbon) accumulate in melanomacrophages (Roberts 1975, Ellis et al. 1976, Ferguson 1984, Tatner \& Manning 1985). In addition, it has been suggested that melanomacrophages are composed of accumulations of sinusoidal macrophages, that have ingested foreign material and (perhaps) moved into the interstitial tissues (Vogelbein et al. 1987, Tsjuii \& Seno 1990, Brattgjerd \& Evensen 1996). The positive immunostaining of sinusoidal macrophages most likely reflects the ability of this cell population to phagocytize particulate material, as also observed for latex particles (Smedsrød et al. 1993). Moreover, the positive immunostaining in kidney sinusoidal endothelial cells is interpreted as uptake of soluble components of the bacterium, which would be in agreement with the observations made for soluble material like collagen (Smedsrød et al. 1993). The importance of macrophage and melanomacrophage involvement in the pathogenesis of infections with Flexibacter psychrophilus is unclear, but our observations suggest that they may 
play a significant role in the infection because they interacted with the bacterium.

In conclusion, the immunohistochemical method for detection of Flexibacter psychrophilus as described in the present study seems to be a reliable and valuable tool for diagnosing and studying RTFS in formalinfixed, paraffin-wax-embedded fry. The study demonstrated that RTFS is a severe septicemic infection that heavily involves the monocyte-macrophage system. Skin changes are also prominent findings in chronic stages of the disease. Further studies are necessary to elucidate the mode of transmission and the route of infection.

Acknowledgements. Thanks are due to Mis Ranủi Tenland and Ms Anita Lauve, Central Veterinary Laboratory, Department of Pathology, Oslo, for skilful technical assistance during the study. This study was supported by a grant from The Nordic Council of Ministers.

\section{LITERATURE CITED}

Baudin-Laurencin F, Castric JC, Vigneulle $M$, Tixerant G (1989) La Myxobactériose viscérale de la truite arc-en-ciel Salmo gardneri R: une forme nouvelle de la maladie de l'eau froide à Cytophaga psychrophila. Bull Acad Vét Fr 62:147-157

Bernardet JF, Baudin-Laurencin F, Tixerant G (1988) First identification of Cytophaga psychrophila in France. Bull Eur Ass Fish Pathol 8:104-105

Bernardet JF, Grimont PAD (1989) Deoxyribonucleic acid relatedness and phenotypic characterization of Flexibacter columnaris sp. nov., nom. rev., Flexibacter psychrophilus sp. nov., nom. rev., and Flexibacter maritimus Wakabayashi, Hikida, and Masumura 1986. Int J Syst Bacteriol 39:346-354

Borg AF (1960) Studies on myxobacteria associated with diseases in salmonid fishes. J Wildl Dis 8:1-85

Brattgjerd S, Evensen $\varnothing$ (1996) A sequential light microscopic and ultrastructural study on the uptake and handling of Vibrio salmonicida in the head kidney phagocytes of experimentally infected Atlantic salmon, Salmo salar L. Vet Pathol (in press)

Bruno DW (1992) Cytophaga psychrophila (Flexibacter psychrophilus) histopathology associated with mortalities among farmed rainbow trout, Oncorhynchus mykiss Walbaum in the UK. Bull Eur Ass Fish Pathol 12:215-216

Bullock GL, Conroy DA, Snieszko SF (1971) Peduncle and coldwater disease. In: Snieszko SF, Axelrod HR (eds) Diseases of fishes. TFH Publications, Jersey City, p 74-77

Chua FH (1991) A study on the rainbow trout fry syndrome. MS thesis, University of Liverpool

Conrad JF, DeCew M (1967) Observations on deformed juvenile coho salmon. Research briefs, Fish Commission of Oregon 13:129

Dalsgaard I, Hørlyck V (1990) Koldtvandssyge eller vintersår hos orreder (Coldwater disease in rainbow trout). Ferskvandsfiskeribladet April:118-120

Elias JM, Gown AE, Nakamura RM, Wilbur DC, Herman GE, Jaffe ES, Battifora H, Brigati DJ (1989) Special report: quality control in immunohistochemistry. Am J Clin Pathol $92: 836-843$
Ellis AE, Munro ALS, Roberts RJ (1976) Defence mechanisms in fish. 1. A study of the phagocytic system and the fate of intraperitoneally injected particulate material in the plaice (Pleuronectes platessa L.). J Fish Biol 8:67-78

Evensen $\varnothing$, Meier $W$, Wahli $T$, Olesen NJ, Jørgensen PEV, Håstein T (1994) Comparison of immunohistochemistry and virus cultivation for detection of viral hemorrhagic septicaemia virus in experimentally infected rainbow trout (Oncorhynchus mykiss). Dis Aquat Org 20:101-109

Ferguson HW (1984) Renal portal phagocytosis of bacteria in rainbow trout: ultrastructural observations. Can J Zool 62: $2505-2511$

Holt RA (1987) Cytophaga psychrophila, the causative agent of bacterial cold-water disease in salmonid fish. PhD thesis, Oregon State University, Corvallis

Holt RA, Amandi A, Rohovec JS, Fryer JL (1989) Relation of water temperature to bacterial cold-water disease in coho salmon, chinook salmon, and rainbow trout. J Aquat Animal Health 1:94-101

Holt RA, Rohovec JS, Fryer JL (1993) Bacterial cold-water disease. In: Inglis V, Roberts RJ, Bromage NR (eds) Bacterial diseases of fish. Blackwell Scientific Publications, Oxford, p 3-23

Kent ML, Groff JM, Morrison JK, Yasutake WT, Holt RA (1989) Spiral swimming behaviour due to cranial and vertebral lesions associated with Cytophaga psychrophila infections in salmonid fishes. Dis Aquat Org 6:11-16

Lehmann J, Mock D, Stürenberg FJ (1988) Zur Ausbreitung der Bakteriellen Kaltwasserkrankheit (BKK) in NordrheinWestfalen. Fischer und Teichwirt 7:206-207

Lorenzen $E$ (1993) The importance of the brand of the beef extract in relation to the growth of Flexibacter psychrophilus in Anacker \& Ordals medium. Bull Eur Ass Fish Pathol 13:64-65

Lorenzen E, Dalsgaard I, From J, Hansen EM, Hørlyck V, Korsholm H, Mellergaard S, Olesen NJ (1991) Preliminary investigations of fry mortality syndrome in rainbow trout. Bull Eur Ass Fish Pathol 11:77-79

Lorenzen E, Karas N (1992) Detection of Flexibacter psychrophilus by immunofluorescence in fish suffering from fry mortality syndrome: a rapid diagnostic method. Dis Aquat Org 13:231-234

Meyers TR (1989) Apparent chronic bacterial myeloencephalitis in hatchery reared juvenile coho salmon Oncorhynchus kisutch in Alaska. Dis Aquat Org 6:217-219

Petrusz P (1983) Essential requirements for the validity of immunocytochemical staining procedures. J Histochem Cytochem 31:177-179

Rimstad $E_{1}$ Evensen $\varnothing$ (1993) The identification of equid herpesvirus 1 in paraffin-embedded tissues from aborted fetuses by polymerase chain reaction and immunohistochemistry. J Vet Diagn Invest 5:174-183

Roberts RJ (1975) Melanin-containing cells of teleost fish and their relation to disease. In: Ribelin WE, Migaki $G$ (eds) The pathology of fishes. The University of Wisconsin Press, Madison, p 399-428

Roberts RJ (1976) Bacterial diseases of farmed fishes. In: Skinner FA, Carr JG (eds) Microbiology in agriculture, fisheries and food. Society for Appl Bact Symp Ser no 4. Academic Press, London, p 55-62

Santos Y, Huntly PJ, Turnbull A. Hastings TS (1992) Isolation of Cytophaga psychrophila (Flexibacter psychrophilus) in association with rainbow trout mortality in the United Kingdom. Bull Eur Ass Fish Pathol 12:209-210

Sarti M, Giorgetti G. Manfrin A (1992) Method for the rapid diagnosis of visceral myxobacteriosis in reared trout in Italy. Bull Eur Ass Fish Pathol 12:53 
Smedsrød B, Gjøen T, Sveinbjornsson B, Berg T (1993) Catabolism of circulating collagen in the Atlantic salmon (Salmo salar). J Fish Biol 42:279-291

Tatner MF, Manning MJ (1985) The ontogenetic development of the reticuloendothelial system in the rainbow trout, Salmo gairdneri Richardson. J Fish Dis 8:189-195

Thuvander A, Fossum C, Lorenzen N (1990) Monoclonal antibodies to salmonid immunoglobulin: characterization and applicability in immunoassays. Dev Comp Immunol 14: $415-423$

Toranzo AE, Barja JL (1993) Fry mortality syndrome (FMS) in Spain. Isolation of the causative bacterium Flexibacter psychrophilus. Bull Eur Ass Fish Pathol 13:30-32

Tsjuii T, Seno S (1990) Melano-macrophage centers in the aglomerular kidney of the sea horse: morphological stud-

Responsible Subject Editor: T. Evelyn, Nanaimo,

British Columbia, Canada ies on its formation and possible function. Anat Rec 226: $460-470$

Vestergaard Jørgensen PE (1974) A study of viral diseases in Danish rainbow trout, their diagnosis and control. Thesis, Veterinary and Agricultural University, Copenhagen

Vogelbein WK, Fournie JW, Overstreet RM (1987) Sequential development and morphology of experimentally induced hepatic melano-macrophage centers in Rivulus marmoratus. J Fish Biol 31 (suppl A):145-153

Wood EM. Yasutake TW (1956) Histopathology of fish. III. Peduncle ('cold-water') disease. Prog Fish-Cult 18:56-61

Wood JW (1974) Diseases of Pacific salmon: their prevention and treatment, 2nd edn. State of Washington, Department of Fisheries, Hatchery Division, Olympia, WA, p $22-24$

Manuscript first received: September 26, 1994

Revised version accepted: November 8, 1995 